\title{
Monitoring cobalt status - experiences in the central North Island
}

\author{
M.F. HAWKE ${ }^{1}$, M.B. O'CONNOR ${ }^{2}$, T.J.M. JOHNSTON ${ }^{3}$, J.E. WALLER ${ }^{2}$ and B. ADDISON ${ }^{2}$ \\ ${ }^{1}$ AgResearch, PO Box 951, Rotorua \\ ${ }^{2}$ AgResearch, Ruakura Agricultural Centre, Pn'vate Bag 3123. Hamilton \\ ${ }^{3}$ BOP Fertiliser Ltd, Private Bag, Mt. Maunganui South
}

\section{A bstract}

The requirement for 'cobalt $(\mathrm{Co})$ of ruminants grazing pastures on the pumice soils of the Central Plateau was established in the late 1930s and Co topdressing to increase the Co intake of animals became commonplace from the mid-1950s. An on-farm survey in 1978-79 indicated that Co inputs could be halved because of adequate reserves of soil Co accumulated since the 1950s. However, the economic downturn in agriculture of the 1980s led to marked reductions in Co use. Follow-up surveys between 1991-93 indicated a general decline in soil and pasture Co levels. This decline was much more pronounced in areas with a poor history of Co topdressing. The 1991-93 survey results indicated a relationship between soil Co and pasture Co, Using probability analysis it was possible to indicate the soil Co level required to maintain a particular pasture Co concentration. For instance, for an $80 \%$ probability of achieving $0.08 \mathrm{mg} / \mathrm{kg}$ DM in the pasture (the critical level for sheep) a soil Co level of 1.7 and $2.2 \mathrm{mg} / \mathrm{kg}$ DM is required for the yellow-brown pumice soils and yellow-brown loams.respectively. Further-surveys are required in other areas to indicate soil Co levels for other soil groups. The 1991-93 surveys have indicated a need to increase the Co level of other soils to prevent Co deficiency in grazing animals. The evidence indicates that a regular Co input is required to build up soil reserves. This input needs to be of the order of $350 \mathrm{~g} \mathrm{CoSO}{ }_{4} .7 \mathrm{H}_{2} \mathrm{O} / \mathrm{ha} /$ year for 7-10 years on the most defîcient areas. The surveys also highlighted the farm by farm variation in their Co status which can exist in a district and hence the need for individual farmers to monitor their soil, pasture and animal Co status. Other factors such as feed quality and grazing strategy can also be important.

Keywords: EDTA soil cobalt, fertiliser practice, pasture cobalt, stock health

\section{Introduction}

The requirement for cobalt (Co) of ruminants grazing pastures on pumice soils was established in the late

1930s (McNaught 1938; McNaught \& Paul 1939). The first signs of $\mathrm{Co}_{0}$ deficiency in sheep were described in the 1890 s for a disease termed 'bush sickness'. Studies were not confined to the pumice soils and regionally the Co deficient disease was called 'Morton Mains disease' in Southland (Dixon 1936), 'Mairoa dopiness' in King Country (Wright \& Taylor 193 1) and 'bush-sickness' in Nelson (Askew \& Dixon 1936). Recommendations for overcoming the deficiency included stock drenches, licks, bullets, soil drenches, use of high $\mathrm{Co}$ limestones, and additions of cobalt in topdressing to increase the $\mathrm{Co}$ content of pastures (Dixon 1936; Dixon \& Kidson 1941; Askew 1945; Andrews \& Prichard 1947).

Cobalt topdressing became common on the pumice soils from the mid-1950s up to the late 1970s with Co being applied as cobalt sulphate $\left(\mathrm{CoSO}_{\mathbf{4}} \cdot \mathbf{7} \mathbf{H}_{2} \mathrm{O}\right)$ at the rate of $3.50 \mathrm{~g} / \mathrm{h} / \mathrm{year}$. The rapid rise in the cost of cobalt prompted farmers to review their use of this additive approach in the late 1970s. A survey of soil and pasture Co levels at that time (Sherrell et al. 1980) suggested annual application rates could be halved from $350 \mathrm{~g} / \mathrm{ha}$ to $175 \mathrm{~g} / \mathrm{ha}$ of cobalt sulphate as a result of the build-up of soil Co concentrations from previous topdressings.

The economic downturn of the 1980s resulted in a decline-in-fertiliser-use;As-with-the rest-of-New-Zealand; the use of fertiliser in the Bay of Plenty declined considerably through this period (Table 1) and many farmers stopped fertilising completely. By the late 1980s increasing incidences of stock health problems associated with $\mathrm{Co}$ deficiency were becoming evident particularly on sheep properties.

Table 1 Fertiliser use in Bay of Plenty.*

\begin{tabular}{|c|c|}
\hline Year & $\%$ of 1982 level \\
\hline $\begin{array}{l}1992 \\
1987 \\
1999 \\
1991\end{array}$ & $\begin{array}{l}100 \\
51 \\
75 \\
76\end{array}$ \\
\hline
\end{tabular}

- Information supplied by T.J.M. Johnston, BOP Fertiliser Ltd, Mount Maunganul

This paper outlines the results of surveys on the Co status of soils and pastures conducted in the Central North Island between 1991 and 1993. Also reported is an 'on farm' monitoring programme undertaken in 1993194. 


\section{M ethod}

\section{Surveys}

In the 1978-80 Central Plateau/Bay of Plenty survey (Sherrell et al. 1980) duplicate pasture samples were collected by hand clipping fresh actively growing herbage in the summer. Both washed and unwashed samples were analysed for pasture Co. Soil samples were taken to $75 \mathrm{~mm}$ depth from the same areas and analysed for Co. One hundred and twenty properties were sampled covering the area from Waihi in the north to Turangi in the south, Mangakino in the west to East Cape in the east.

The 1991 survey covered a similar area to the 197880 survey (Figure 1) but only 72 of the original properties were sampled mainly because of land use change or geographical spread. Duplicate pasture and soil samples were taken from the same paddocks as for the earlier survey. Samples were taken in the summer and were not washed. Information on fertiliser practices together with records on stock health where available were collected.

Figure 1 Areas surveyed in central North Island study of the Co status of soils and pastures.

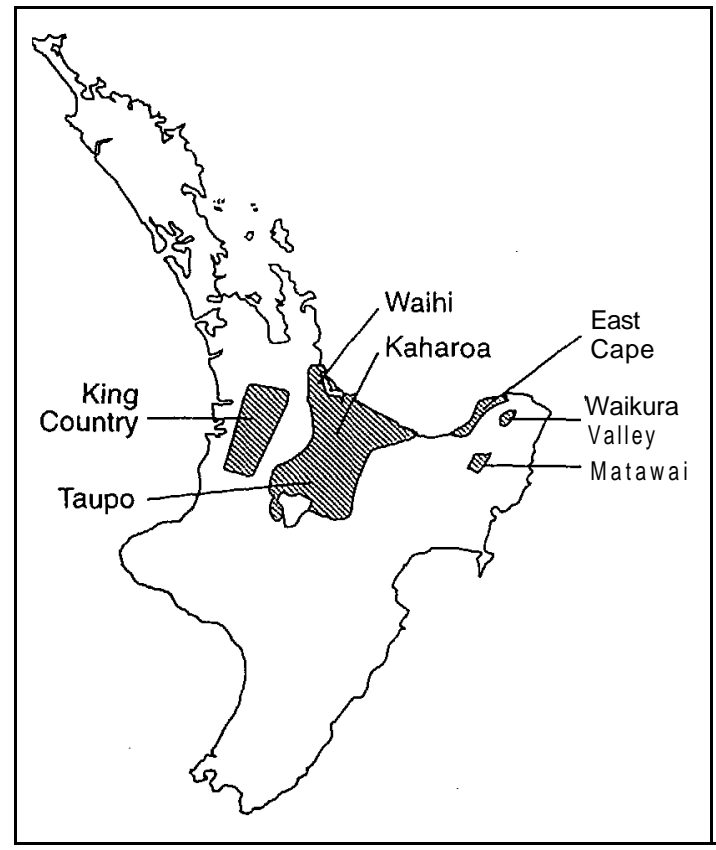

In 1992, 31 properties in the King Country were surveyed and in 1993, 10 properties were sampled in the Waikura Valley and Matawai areas (Figure 1). In these surveys no base line information was available from previous analysis.

\section{On-farm monitoring}

As an example of on-farm monitoring, a sheep/beef property at Tihoi (Western Bays, Lake Taupo) which had received Co topdressing in the past and most recently in July 1993 was monitored over the 1993/94 season. Soil samples taken initially (October 1993) were analysed for EDTA-extractable $\mathrm{Co}$, pasture samples were taken monthly for $\mathrm{Co}_{0}$ concentration, serum $\mathbf{B}_{12}$ determinations were carried out on wether lambs during December 1993, January and February 1994, and liver $\mathbf{B}_{\mathbf{1 2}}$ analysis on 10 lambs was carried out at slaughter (March 1994).

\section{Analysis}

Pasture and soil samples were analysed by the AgResearch Soil Fertility Service for herbage Co and EDTA-extractable soil Co using the method described by Sherrell (1990).

\section{Statistics}

A Bayesian smoothing technique (program Flexi 2.2 Wheeler \& Upsdell 1994) was used to estimate the fitted values and their confidence intervals from the relationship between pasture Co concentrations and EDTA-extractable soil Co concentrations. The relationships were estimated separately for yellowbrown pumice and yellow-brown loam soils. The probability that the pasture cobalt concentration exceeded $0.08 \mathrm{mg} / \mathbf{k g}$, the critical concentration for sheep (Clark 1983), was then obtained.

\section{Results and discussion}

\section{Survey results}

Cobalt fertiliser history plays a dominant role in maintaining an adequate $\mathrm{Co}_{0}$ status on cobalt deficient farms. Those farms with a long history of regular $\mathrm{Co}$ usage (20 years or more) have maintained higher soil and pasture Co status than farms with a poor $\mathrm{Co}_{0}$ fertiliser history (Table 2). This has occurred in spite of irregular Co use between 1980 and 1991-93 and a decline in the rate of Co applied (from 350 to $175 \mathrm{~g} / \mathrm{ha} /$ annum). Sheep and beef properties generally have lower $\mathrm{Co}$ status than dairy farms (Table 3)

Relationships between EDTA-extractable soil Co and pasture Co, from the 1991-93 surveys, are shown in Figures 2 and 3 for the yellow-brown pumice soils and yellow-brown loams respectively. Fitted lines and confidence intervals were obtained using a Bayesian smoothing technique (Wheeler \& Upsdell 1994).

Actual EDTA-extractable soil Co concentrations required to achieve a particular $\mathrm{Co}_{0}$ concentration in the plant (together with confidence intervals) can be obtained from these graphs. However the range of values 
Table 2 Pasture cobalt and EDTA-extractable soil cobalt status ( $\mathbf{m g} / \mathbf{k g ~ D M}$ ) of various central North Island districts.

(a) Long history of regular Co use prior to 1979/80, irregular since 1960

\begin{tabular}{|c|c|c|c|c|c|c|c|c|}
\hline \multirow[t]{2}{*}{ Year } & \multicolumn{2}{|c|}{-- Kaharoa/Mamaku .. } & \multicolumn{2}{|c|}{......- - Taupo -......... } & \multicolumn{2}{|c|}{$\ldots . . .$. East Cape ....... } & \multirow{2}{*}{$\begin{array}{l}\text { Waikura Valley } \\
\text { Plant Co }\end{array}$} & \multirow{2}{*}{$\begin{array}{c}\text { Matawai' } \\
\text { Soil Co }\end{array}$} \\
\hline & Plant Co & Soil co & Plant Co & Soil $C_{0}$ & Plant Co & Soil $C_{0}$ & & \\
\hline 1979180 & 0.21 & 1.59 & 0.30 & 1.59 & 0.18 & 1.97 & & \\
\hline 1991193 & 0.13 & 1.12 & 0.14 & 1.39 & 0.12 & 1.74 & 0.10 & 1.01 \\
\hline
\end{tabular}

(b) Poor history of Co use

\begin{tabular}{lccccc}
\hline Year & \multicolumn{2}{c}{ W....... Waihi } & & \multicolumn{2}{c}{ W... King Country -... } \\
& Plant Co & Soil co & & Plant Co & Soil Co \\
\hline $1979 / 80$ & 0.10 & 1.15 & & \\
$1991-93$ & 0.06 & 0.80 & 0.08 & 1.30
\end{tabular}

* Fertiliser Co usage always irregular

Table 3 A comparison of pasture cobalt and EDTA-extractable soil cobalt concentrations (mg/kg DM) between sheep/ beef and dairy farms.

\begin{tabular}{lllcc}
\hline District & \multicolumn{2}{c}{ Farm type } & Pasture Co & Soil Co \\
\hline \multirow{2}{*}{ King Country } & Dairy & $(\mathbf{( 1 2 )}$ & 0.08 & 1.60 \\
& Sheep & $(5)$ & 0.05 & 0.80 \\
\multirow{2}{*}{ East Cape } & Dairy & $(5)$ & 0.13 & 1.94 \\
& Sheep/beef & $(5)$ & 0.11 & 1.53 \\
\hline
\end{tabular}

() number of samples

from the surveys is quite wide which means the degree of precision in a practical sense is limited. An alternative presentation of the data is to consider the percentage probability of óbtaining a certain pasture Co concentration given a range of soil Co values. For example, we know the critical concentration of $\mathrm{Co}_{0}$ in the pasture for sheep is $0.08 \mathrm{mg} / \mathrm{kg}$ (Clark \& Millar 1983). The question really is what level of EDTAextractable soil Co is needed to exceed this critical concentration of $0.08 \mathrm{mg} / \mathrm{kg}$ in the pasture. Figures 4 and $\mathbf{5}$ show the soil Co status required to exceed 0.08 $\mathrm{mg} / \mathrm{kg}$ in the pasture expressed as a percentage probability for yellow-brown pumice soils and yellowbrown loams respectively. If $80 \%$ probability was accepted as a reasonable goal then on a yellow-brown pumice soil it would require a soil Co concentration of $1.7 \mathrm{mg} / \mathrm{kg}$ and on a yellow-brown loam $2.2 \mathrm{mg} / \mathrm{kg}$. Obviously the higher the EDTA-extractable soil Co concentration the higher the pasture $\mathrm{Co}$ concentration but taking an $80 \%$ probability value appears to give values which are close to maximum (Figures 4 and 5). Other major soil groups for New Zealand need to be surveyed to allow similar relationships to be developed. In this regard information will soon be available for Otago and Southland (J. Morton pers. comm.).
Figure 2 Relationship between EDTA-extractable soil $\mathrm{C}_{0}$ and plant Co concentrations on yellow-brown pumice soils.

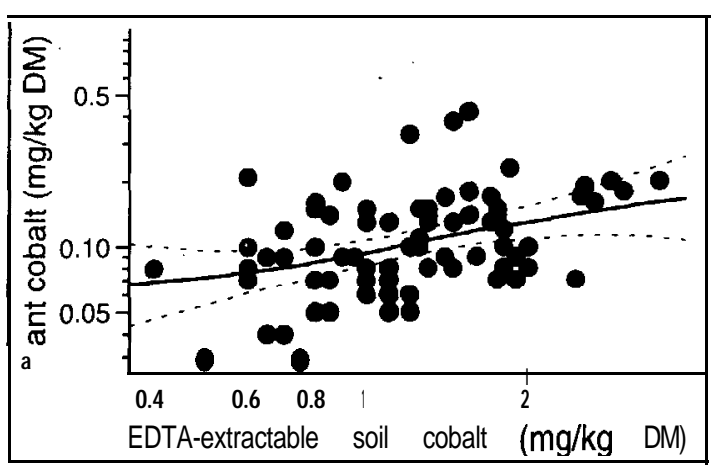

Figure 3 Relationship $\overline{\text { between EDTA }} \overline{\text { extractable soil } \mathrm{Co}}$ and plant $\mathrm{Co}_{0}$ concentrations on yellow-brown loam soils.

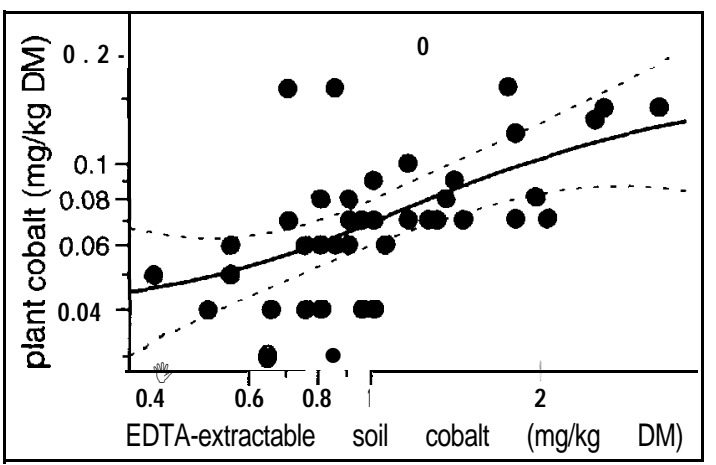

Surveys of this type require a general set of guidelines.

(a) Pastures should be sampled at the same time of the year, that is during summer to indicate the lowest Co values (Toxopeus 1989).

(b) Pastures need to be analysed for titanium and iron as a measure of soil contamination. 
Figure 4 Percentage probability that plant Co concentrations exceed $0.08 \mathbf{~ m g} / \mathbf{k g}$ DM on yellow-brown pumice soils.

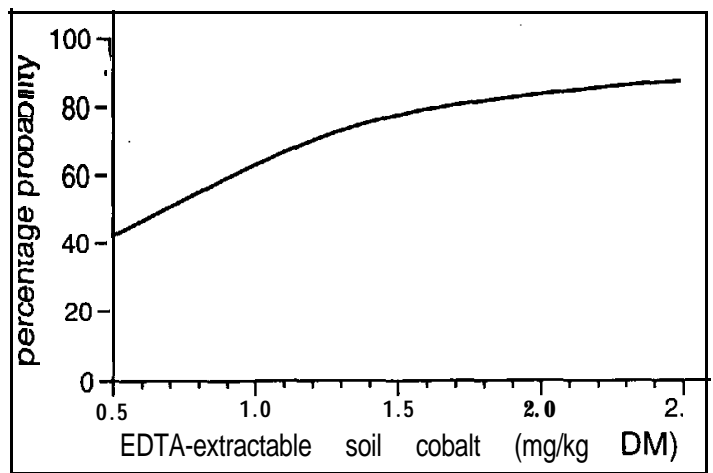

Figure 5 Percentage probability that plant $\mathrm{C}_{0}$ concentrations exceed $0.08 \mathrm{mg} / \mathrm{kg}$ DM on yellow-brown loam soils.

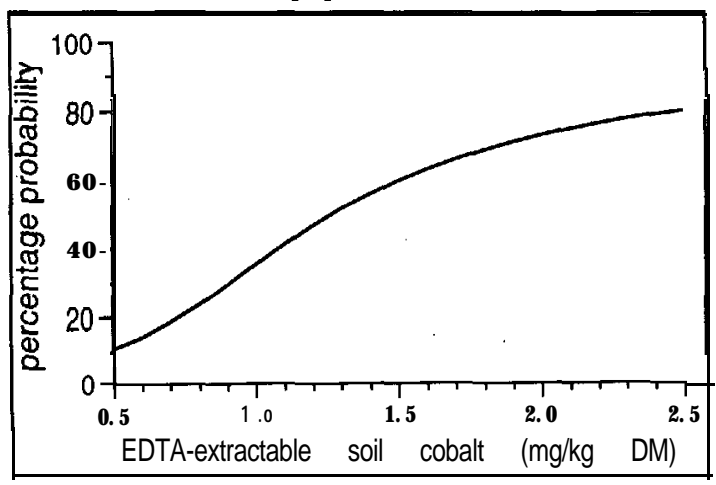

(c) Laboratory analyses of the samples must be standardised.

(d) Records of previous fertiliser Co usage and date of application, together with other fertiliser and lime use should be obtained.

(e) Animal tissues, namely serum and liver need to be sampled and analysed for vitamin B 12

\section{On-farm monitoring}

On a sheep/beef property at Tihoi, cobalt sulphate was applied in the fertiliser in July 1993 at a rate of $350 \mathrm{~g} /$ ha. The ETDA-extractable soil Co concentration in October was $1.4 \mathrm{mg} / \mathrm{kg}$ (Table 4). Monthly pasture Co concentrations indicated adequate $\mathrm{Co}_{0}$ in the herbage to meet animal requirements through to January 1994. Thereafter pasture Co concentrations declined and were below the critical level by April 1994 while the serum and liver vitamin $\mathbf{B}_{12}$ concentrations in lambs were all adequate in March 1994. The farmer noted that an injection of vitamin $\mathbf{B}_{12}$ in his ewe lambs in April gave a positive visual response in lamb vigour and appearance.
It was difficult however to separate the effect of a $\mathbf{B}_{12}$ injection with a general improvement in feed quality associated with the onset of autumn growth.

Table 4 Monitoring the cobalt status of a Tihoi sheep/beef property (yellow-brown pumice soil) 1993-94.

Oct Nov Dec Jan Feb Mar April

Soil Co $(\mathrm{mg} / \mathrm{kg}) \quad$ (2) 1.4

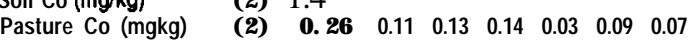

$\begin{array}{lllll}\text { Serum } B_{10} \text { (p mol/R) } & \text { (10) } & 1525 \quad 2080 & 1570\end{array}$

$\begin{array}{lll}\text { Liver } \mathbf{B}_{12} \text { (n molkg) } & (10) & 391\end{array}$

() number of samples

Applying the probability analyses for a yellowbrown pumice soil (Figure 4) to this property would indicate there was a 74\% probability of exceeding 0.08 $\mathrm{mg} / \mathrm{kg}$ in the pasture with a soil $\mathrm{Co}$ of $1.4 \mathrm{mg} / \mathrm{kg}$. This suggests that a soil value higher than 1.4 , and probability greater than $\mathbf{7 4 \%}$, is required to achieve an adequate herbage Co status throughout the year. Hence our suggestion of using $80 \%$ probability which would require $1.7 \mathrm{mg} / \mathrm{kg}$ soil Co. Forbes (1976) calculated that it would take 25 years of applying $350 \mathrm{~g} / \mathrm{ha} / \mathrm{year}$ cobalt sulphate to raise soil Co by $3.3 \mathrm{mg} / \mathrm{kg}$. To increase soil Co from 1.4 to $1.7 \mathrm{mg} / \mathrm{kg}$ on the same basis would take 2 to 3 years at $350 \mathrm{~g} / \mathrm{ha} / \mathrm{yr}$.

\section{Other factors}

A number of factors influence the amount of $\mathrm{Co}$ in the pasture and hence the severity of Co deficiency in stock:

\section{Timing of Co topdressing}

The applications of cobalt sulphate elevate Co levels in herbage for only a short period of 3 to 4 months (Metherell 1989; Sherrell 1990). Hence spring rather than autumn topdressing is necessary to ensure adequate herbage $\mathrm{Co}_{0}$ concentrations over the summer/autumn period for young sheep which are most sensitive to Co deficiency. Where there has been a long history of regular Co fertiliser application, e.g., $350 \mathrm{~g} / \mathrm{ha} / \mathrm{yr}$ for 7-10 years (Sherrell 1990) then timing of subsequent Co fertiliser applications becomes less important as Co becomes available from soil reserves (Forbes 1976).

\section{Sorption of Co by the soil}

Forbes (1976) showed that only about $1 \%$ of the Co applied annually was taken up by the pasture, the remainder being sorbed by the soil. Some of this soil $\mathrm{Co}_{\mathrm{O}}$ is available for uptake by pasture plants. High soil manganese $(\mathrm{Mn})$ has been implicated in sorption of $\mathrm{Co}_{0}$ in some Tasmanian soils (Adams et al. 1969) but Mn content of pumice soils is relatively low and is likely to 
have minimal effect on the amount of Co absorbed by pasture (Forbes 1976). This needs to be investigated for other soil groups in New Zealand.

\section{Sward composition and stocking rate}

Long pasture has lower Co levels than short pasture (McNaught \& Paul 1939) and clover has higher Co levels than ryegrass (Sherrell 1990). Light grazing is also more likely to induce $\mathrm{Co}$ deficiency than heavy grazing as the heavy grazed pastures may be contaminated with soil and cause increased animal Co intake (Andrews 1971).

Some animal health problems are associated with Co deficiency. Many farmers in the surveys considered Co 'ill-thrift' to be an all encompassing stock health problem. Other trace elements like selenium were often ignored and internal worm burdens were occasionally high. The surveys have also highlighted the marked farm to farm variation which can occur in a district with respect to the Co status of soils and pastures. Surveys can indicate average effects across a district or soil group' but individual farmers need to embark on regular on-farm monitoring programmes to determine Co status of their soils, pastures and animals.

\section{Conclusions}

Cobalt deficiency in grazing ruminants is a well known and documented trace element problem on the pumice soils of the central North Island. It has been the subject of considerable research in the past. Surveys are a useful method of monitoring changes in cobalt status in a district or on particular soil groups. Bench-mark pasture and soil $\mathrm{Co}$ concentrations need to be established along with Co topdressing history and animal health and performance. Subsequent analysis should be from the same farms and at the same time of the year.

The 1991-93 surveys have highlighted the need to increase the $\mathrm{Co}$ concentrations of soils in areas outside the pumice plateau for example Waihi and the King Country. The relationship between EDTA-extractable soil $\mathrm{Co}_{0}$ and plant $\mathrm{Co}_{0}$ concentrations can be used to indicate the likely soil Co concentrations required (with $80 \%$ probability at least) to maintain pasture Co above the critical level to meet animal dietary $\mathrm{Co}$ requirements throughout the year. Regular $\mathrm{Co}$ inputs are required to build up soil $\mathrm{Co}$ reserves and the capital inputs of $350 \mathrm{~g}$ $\mathrm{CoSO}_{4} / \mathrm{ha} / \mathrm{yr}$ for 7-10 years may have been neglected in the past.

It is important for farmers to monitor the Co status of soils, pastures and animals on their farms. Appropriate action can then be taken whether it be a short term remedy like vitamin $\mathbf{B}_{12}$ injections every 4-6 weeks or a more long-term approach such as an annual Co topdressing. It is important to realise that other on-farm factors such as feed quality and grazing strategy can influence the Co status of lambs.

\section{ACKNOW LEDGEMENTS}

Bryan Marris and Tom Gee for field assistance, the farmers, Landcorp and Mr R. Cottrell, Tihoi for the use of their properties and the Soil Fertility Service staff for sample analysis. The earlier work of Ken McNaught, George Sherrell and Neil Percival and to the Bay of Plenty Fertiliser Company Ltd for funding of and field assistance with the recent surveys.

\section{REFERENCES}

Adams, S.N.; Honeysett, J.L.; Tiller, K.G.; Norrish, K. 1969. Factors controlling the increase of cobalt in plants following the addition of a cobalt fertiliser. Australian journal of soil research 7:29-42.

Andrews, E.D. 1971. Cobalt deficiency in sheep and cattle. NZ Department of Agriculture bulletin 180. Wellington, NZ Government Printer.

Andrews, E.D.; Prichard, A.M. 1947. Topdressing cobalt-deficient land from the air. $N Z$ journal of agriculture 75: 501-506.

Askew, H.O.; Dixon, J.K. 1936. The importance of cobalt in the treatment of certain stock ailments in the South Island, New Zealand. NZ journal of science and technology 18: 73-92.

Askew, H.O. 1945. The control of cobalt deficiency at Sherry_River,_Nelson._NZ_journal_of_science_and technology 26: 216-222.

Clark, R.G.; Millar, K.R. 1983. Cobalt. The mineral requirements of grazing ruminants. Ed. N.D. Grace. NZ Society of Animal Production: $150 \mathrm{pp}$.

Dixon, J.K. 1936. Investigations on a sheep ailment in Southland. NZ journal of science and technology 17: 600-619.

Dixon, J.K; Kidson, E.B. 1941. The effect of a heavy dressing of a Southland limestone on the health of lambs at Morton Mains. NZ journal of science and technology 22: 1-6.

Forbes, E.A. 1976. Cobalt, copper and zinc in yellowbrown pumice soils under grazed permanent pastures. NZ journal of agricultural research 19: 153-164.

McNaught, K.J. 1938. The cobalt content of North Island pastures. NZ journal of science and technology 20: 14-30.

McNaught, K.J.; Paul, G.W. 1939. Seasonal variation in cobalt content of North Island pastures. NZ journal of science and technology 21: 95- 101.

Metherell, A.K.; 1989. The cobalt enigma - some 
observations and strategies for Otago and Southland. Proceedings of the New Zealand Grassland Association 50: 101- 108.

Sherrell. C.G.; Percival, N.S.; Poole, P.R. 1980.

Reducing cobalt applications on pumice soils. Proceedings Ruakura Farmers' Conference 32: 71 77.

Sherrell, C.G. 1990. Effect of cobalt application on the cobalt status of pastures 2. Pastures without previous cobalt application. NZ journal of agricultural research 33: 305-311.

Toxopeus, M.R.J. 1989. Lime responses in sheep grazing pastures on yellow brown loams of the northern King Country, North Island, New Zealand. NZ journal of agricultural research 32: 81-94.

Wheeler, D.M.; Upsdell, M.P. 1994. Flexi 2.2 Reference Manual, Biometrics Section, NZ Pastoral Agricultural Research Ltd, Ruakura Agricultural Centre, Private Bag 3123, Hamilton, New Zealand

Wright, C.M.; Taylor, N.H. 1931. A successful experiment on sheep-sick country in Mairoa district. NZ journal of science and technology 13: 57-75. 